\title{
Influence of gender in pathogenesis of trichomoniasis in congenitally athymic (nude) mice
}

\author{
M G MARTINOTTI, T MUSSO, D SAVOIA \\ From the Institute of Microbiology, University of Turin, Turin, Italy
}

SUMMARY Evaluation of abscesses appearing in male and female euthymic and athymic (nude) $\mathrm{Balb} / \mathrm{c}$ mice after subcutaneous injection of Trichomonas vaginalis in the dorsal region showed that females were more susceptible than males. Female euthymic mice, however, were more susceptible than male athymic mice, and splenectomised athymic males were more susceptible than nonsplenectomised athymic males. $F_{1}$ female athymic mice were the most susceptible, as their abscesses reached a peak size five days earlier than those of athymic homozygous females. $F_{1}$ male athymic mice, though slightly more susceptible than athymic homozygous males, did not develop abscesses that were similar in size. These results suggest that resistance or susceptibility to $T$ vaginalis infection depends on the gender of the host and on thymus dependent cellular populations.

Trichomonas vaginalis is a cosmopolitan parasite that inhabits male and female genitourinary tracts.' In most men infection is symptomless and the clinical picture is uncertain, ${ }^{2}$ whereas in women trichomoniasis produces pronounced vaginal inflammation, physical distress, and cytopathological tissue changes. $^{34}$ Numerous workers have reported that the gender of the host affects the establishment, development, growth, or reproduction of a wide variety of protozoan and helminthic parasites. ${ }^{5-13}$

Experimental infection with $T$ vaginalis in laboratory animals can be transmitted by different routes.' Our previous studies have shown the influence of gender and sex hormones on the uptake and development of $T$ vaginalis infection in Balb/c mice. ${ }^{1014}$ Athymic (nude) mice have been extensively used in the laboratory to evaluate the importance of $\mathrm{T}$ lymphocytes in the pathogenesis of metazoan and protozoan infections. ${ }^{15} 18$ The inability of athymic mice to mount effective cell mediated immune responses ${ }^{19-21}$ is thought to be due to their lack of a thymus. ${ }^{223} \mathrm{We}$ therefore thought that it would be interesting to compare the responses of male and female athymic mice to infection with $T$ vaginalis and evaluate the

Address for reprints: Dr Maria Giovanna Martinotti, Istituto di Microbiologia, Facolta' di Medicina e Chirurgia, Via Santena 9, 10126 Torino, Italy

Accepted for publication 10 May 1987 importance of $\mathrm{T}$ cells in the pathogenesis of trichomoniasis.

\section{Materials and methods}

MICE

We used male and female six to seven week old Balb/c athymic mice and their white euthymic litter mates. In some experiments we used male and female $F_{1}$ Balb/c athymic mice, which had been obtained by mating homozygous athymic mice. The animals were maintained in sterile plastic boxes at $26^{\circ} \mathrm{C}$ and fed sterile pellet food (Piccioni, Brescia) and sterile water with antibiotics ad libitum.

\section{PARASITES}

Strain D of $T$ vaginalis was isolated from a woman with acute vaginal infection, and was maintained axenically in modified Diamond's medium ${ }^{24}$ supplemented with $10 \%$ heat inactivated fetal calf serum containing $100 \mathrm{IU} / \mathrm{ml}$ penicillin, $100 \mu \mathrm{g} / \mathrm{ml}$ streptomycin, and $20 \mathrm{IU} / \mathrm{ml}$ mycostatin. The stock preparation was then frozen at $-80^{\circ} \mathrm{C}$ in $10 \%$ dimethylsulphoxide. Samples were thawed five days before use, and the challenge inocula were obtained after two passages in Diamond's medium. Virulence was evaluated before the beginning of these experiments by injecting progressive doses intraperitoneally in Balb/c mice and noting the speed of their deaths. 
SUBCUTANEOUS INFECTION

We injected $0.25 \mathrm{ml}$ of a suspension in Hank's balanced salt solution containing $1 \times 10^{6}$ viable $T$ vaginalis organisms subcutaneously in the dorsal region of 10 male and 10 female athymic mice and eight male and eight female white euthymic mice. Each animal was examined every other day from day 4 after injection in accordance with Honigberg's "subcutaneous mouse assay".25

\section{SPLENECTOMY}

When splenectomy was required, we made a $5 \mathrm{~mm}$ long incision on the left upper flank. One or two stitches were enough to close the wound, which usually healed within one week.

\section{STATISTICS}

Using Student's $t$ test, we compared the mean volumes of abscesses observed in different groups of mice. A difference of more than $p=0.05$ was considered to be not significant.

\section{Results}

\section{INFLUENCE OF GENDER ON T VAGINALIS}

INFECTION IN ATHYMIC MICE

Figure 1 shows that athymic females were more susceptible than athymic males. Their subcutaneous abscesses developed within four to six days and peaked

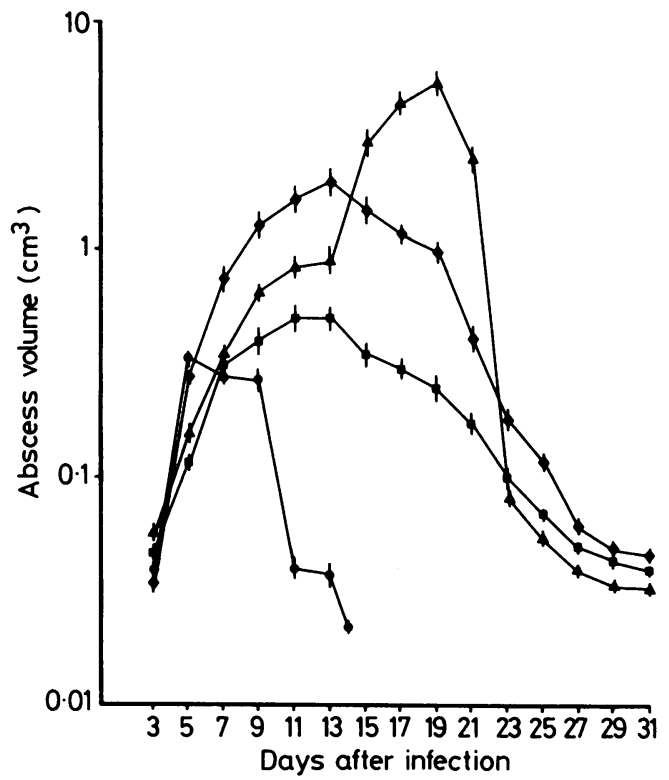

Figure 1 Mean (SD) abscess volume of eight euthymic male ( ), eight euthymic female ( ), 10 athymic male (D), and 10 athymic female ( $\Delta$ ) Balb/c mice after subcutaneous infection with Trichomonas vaginalis.

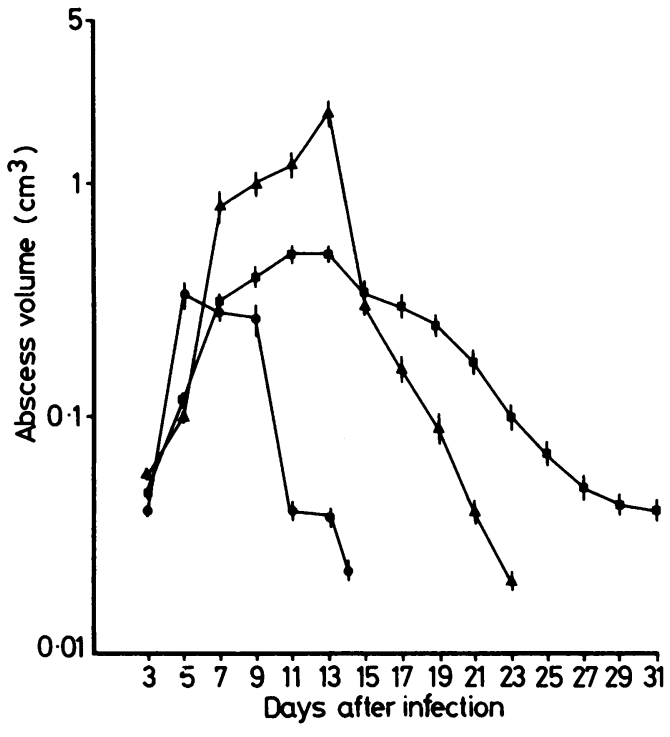

Figure 2 Mean (SD) abscess volume of eight euthymic male (O). eight athymic male ( ), and 10 splenectomised athymic male $(\Delta)$ Balb/c mice after subcutaneous infection with Trichomonas vaginalis.

after 17 to 20 days. By contrast, in athymic males the abscesses were always appreciably smaller than in athymic females, developed in four to six days, and peaked in 11 to 13 days.

Heterozygous males and females were more resistant than their homozygotes to subcutaneous infection, though euthymic females were more susceptible than euthymic males. Abscess volumes in male and female euthymic mice were appreciably less than in athymic mice.

INFLUENCE OF SPLENECTOMY OF ATHYMIC MALE

MICE ON INFECTION WITH T VAGINALIS

Figure 2 shows that splenectomy did not influence the onset of abscesses, but after day 7 the volumes in splenectomised mice peaked to appreciably higher values. Moreover, these abscesses started to decrease more quickly (after 15 days) and disappeared in about 23 days.

T VAGINALIS INFECTION IN F, ATHYMIC MICE To evaluate whether subsequent generations of male and female athymic mice maintained susceptibility that depended on their gender, we tested the $F_{1}$ animals of both sexes obtained by mating homozygous athymic mice.

$F_{1}$ female athymic mice were the most susceptible to $T$ vaginalis infection (fig 3 ). Abscess sizes peaked in 13 to 15 days, five days earlier than observed in homozygous athymic females. $F_{1}$ male athymic mice, 


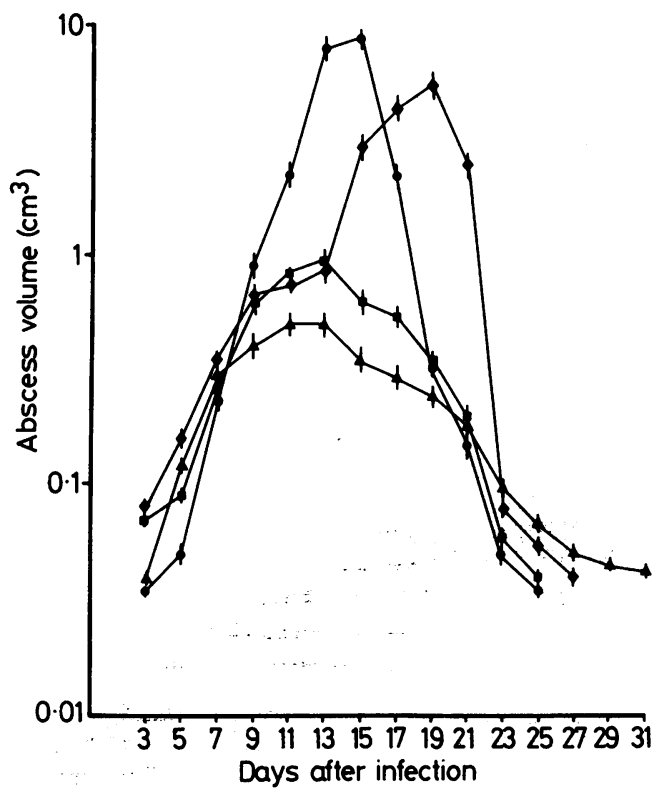

Figure 3 Mean (SD) abscess volume of $10 F_{1}$ athymic femále (O), $10 F_{1}$ athymic male ( $)$ ), 10 homozygous athymic female $(\bullet)$, and 10 homozygous athymic male $(\boldsymbol{\Delta})$ Balb/c mice after subcutaneous infection with Trichomonas vaginalis.

while slightly more susceptible than homozygous athymic males, did not develop appreciably larger abscesses.

\section{Discussion}

These results show clearly that susceptibility to $T$ vaginalis infection depends on gender in both euthymic and athymic mice (figure 1), that thymus dependent cell populations modulate both the onset and progress of infection, and that female hormones are important in increasing the possibility of a subcutaneous take. ${ }^{1014}$

Differences in the immune responses of males and females of the same species have often been described. The lymphocytes of males are more efficient effector cells in antibody dependent cellular cytotoxicity. ${ }^{26}$ Females are more likely to develop autoimmune diseases. ${ }^{27}$ Some workers have recently observed an influence of gender on the pathogenesis of Trypanosoma rhodesiense ${ }^{9}$ and Leishmania major ${ }^{8}$ infection in mice. Moreover, in the Middle East women are more prone than men to develop incurable recurrent-leishmaniasis and display a poorer response to vaccination with attenuated $L$ major strains. ${ }^{28}$

Splenectomy of athymic male mice did not accelerate $T$ vaginalis takes, but did increase abscess size to values appreciably greater than in non-splenectomized athymic males (fig 2). Splenectomy, of course, deprived the athymic animals of an anatomical site rich in natural killer cells. ${ }^{29}$

It is thus likely that both gender (and in particular its associated hormones) and pre-T cells co-operate to make males resistant to $T$ vaginalis infection. Furthermore, our previous work has shown that treatment of euthymic male mice with oestrogens enhances their sensitivity to subcutaneous trichomoniasis. ${ }^{14}$

$F_{1}$ athymic mice obtained by recrossing homozygotes maintained this gender linked sensitivity (fig 3). Pronounced differences were not noted between abscesses formed in $F_{1}$ males and females compared with their respective homozygotes. Here again, females were more susceptible than males. Abscesses did, however, develop more quickly in $F_{1}$ females than in their homozygotes. In males, too, there was a slight increase in abscess size, though the absence of oestrogens served to maintain a considerable degree of resistance.

In conclusion, athymic mice are more susceptible than euthymic mice to subcutaneous $T$ vaginalis infection. This emphasises the importance of the T cell mediated immune response in preventing trichomoniasis. As far as the greater susceptibility of females is concerned in both euthymic and athymic animals, treatment of female mice with diethylstylbestrol has recently been shown to decrease spleen cell production of interleukin-2, which results in enhanced susceptibility to Listeria monocytogenes. ${ }^{30}$ Weakening the $\mathrm{T}$ cell response by oestrogens is therefore probably responsible for greater susceptibility in females.

We thank Dr J Iliffe for his careful review of the manuscript. This work was supported by a grant from Italian Ministero Pubblica Istruzione.

\section{References}

I Honigberg BM. Trichomonads of importance in human medicine. In: Kreier JP, ed. Parasite protozoa. Vol II. New York: Academic Press, 1978: 275-454.

2 Krieger JM. Urologic aspects of trichomoniasis. Invest Urol 1981;18:411-36.

3 Rein MF, Chapel TA. Trichomoniasis, candidiasis and the minor veneral diseases. Clin Obstet Gynecol 1975;18:73-9.

4 Spence MR, Hollander DM, Smith J, McCaig L, Sewell D, Brockman M. The clinical and laboratory diagnosis of Trichomonas vaginalis infection. Sex Transm Dis 1980;7:168-75.

5 Denham DA. Studies with Brugia pahangi. 6 . The susceptibility of male and female cats to infection. $J$ Parasitol 1974;60:642-9.

6 Dubey JP, Hoover EA, Walls KW. Effect of age and sex on the acquisition of immunity to toxoplasmosis in cats. J Protozool 1977;24:184-6.

7 Frahya GJ, Lawlor WK, Dajani RM. Echinococcus granulosus in albino mice: effect of host sex and sex hormones on the growth of hydatid cysts. Exp Parasitol 1971;29:255-62.

8 Giannini MSH. Sex-influenced response in the pathogenesis of 
cutaneous leishmaniasis in mice. Parasite Immunol 1986;8:31-7.

9 Greenblatt HC, Rosenstreich DL. Trypanosoma rhodesiense infection in mice: sex-dependence of resistance. Infect Immun 1984;43:337-45.

10 Landolfo S, Martinotti MG, Martinetto P, Forni G, Rabagliati AM. Trichomonas vaginalis: dependence of resistance among different mouse strains upon the non-H-2 gene haplotype, sex, and age of recipients hosts. Exp Parasitol 1981;52:312-8.

11 Mankau S, Hamilton R. The effect of sex and sex hormones on the infection of rats with Trichinella spiralis. Canadian Journal of Zoology 1973;50:579-86.

12 Mankau S. Host sex and sex hormones as a factor affecting Trypanosoma lewisi population in white rats. Jap J Parasitol 1975;24:47-52.

13 Reddington JJ, Stewart GL, Kramar GW, Kramar MA. The effects of host sex and hormones on Trichinella spiralis in the mouse. J Parasitol 1981;67:548-53.

14 Martinotti MG, Martinetto P. Landolfo S. Effect of estradiol on natural resistance: in vivo and in vitro studies. Microbiologica 1981;4:181-6.

15 Heine J, Moon HW, Woodmansee DB. Persistent Cryptosporidium infection in congenitally athymic (nude) mice. Infect Immun 1984;43:856-9.

16 Ito A. Thymus dependency of induced immune responses against Hymenolepis nana using congenitally athymic nude mice. Clin Exp Immunol 1985;60:87-94.

17 Mitchell GF. Metazoan and protozoan parasitic infections in nude mice. Contemporary Topics in Immunobiology 1978;8:55-74.

18 Roberts-Thompson IC, Mitchell CF. Giardiasis in mice. I. Prolonged infection in certain mouse strains and hypothymic (nude) mice. Gastroenterology 1978;75:42-9.

19 Pantelouris EM. Observations on the immunobiology of nude mice. Immunology 1971;20:247-54.

20 Pritchard H, Micklem HS. Immune responses in congenitally thymusless mice. I. Absence of response of oxazolone. Clin Exp Immunol 1972;10:151-62.

21 Wortis HH. Immunological responses of nude mice. Clin Exp Immunol 1971;8:305-12.

22 Goldstein P, Wigzell H, Blomgren H, Swedmy EAJ. Cells mediating specific in vitro cytotoxicity. II. Probable autonomy of thymus processed lymphocytes ( $T$ cells) for killing allogeneic target cells. J Exp Med 1972;135:890-903.

23 Wagner H, Haris AW, Feldman M. Cell-mediated immune response in vitro. II. The role of thymus and thymus derived lymphocytes. Cell Immunol 1972;4:39-45.

24 Cappuccinelli P, Lattes C. Cagliani I. Coltivazione in monostrato di Trichomonas vaginalis. In: Atti del XVI Congresso Nazionale di Microbiologia. Pisa: Giardini, 1973;3:411-6.

25 Honigberg BM. Comparative pathogenicity of Trichomonas vaginalis and Trichomonas gallinae to mice. I. Gross pathology, quantitative evaluation of virulence and some factors affecting pathogenicity. J Parasitol 1961;47:545-71.

26 Santoli D, Trinchieri G, Zmijewski CM, Koprowski H. HLA related control of spontaneous and antibody dependent cellmediated cytotoxic activity in humans. $J$ Immunol 1976;117:765-74.

27 Goidl EA, Weksler ME. Autoimmunity. In: Safai B, Good RA, eds. Immunodermatology. New York: Plenum Medical Book Co, 1981:313-67.

28 Greenblatt CL. The present and future of vaccination for cutaneous leishmaniasis. In: New developments with human and veterinary vaccines. New York: AR Liss Inc, 1980:259-82.

29 Herberman RB, Holden HT. Natural cell-mediated cytotoxicity. Adv Cancer Res 1978;27:305-34.

30 Pung OJ, Tucker AN, Vore SJ, Luster MI. Influence of estrogen on host resistance: increased susceptibility of mice to Listeria monocytogenes correlates with depressed production of interleukin 2. Infect Immun 1985;50:91-6. 